\title{
ATTACHMENT FORMATION WITHIN ADOPTIVE FAMILIES AND POST-ADOPTION SUPPORT
}

\author{
N. MIHOC ${ }^{1} \quad$ G. DIMA
}

\begin{abstract}
This study aims to explore the experience of the adoptive families related to the attachment formation with the adopted child. Existing post-adoption services are explored. The study design is qualitative and triangulated the data from interviews with 11 adoptive parents, with a wide range of attachment relationship experience, from observation within a support group for adoptive parents, from interviews with specialists working in the statutory and private sector in the adoption field, and from social documents. Data analysis made use of the thematic analysis and storytelling. The key factors facilitating the attachment process are discussed and several recommendations for post-adoption services are made.
\end{abstract}

Keywords: attachment, adoption, post-adoption services.

\section{Introduction}

The large number of abandoned children in Romania, as well as the awareness-raising campaigns on the growth of this phenomenon have turned adoption into an issue of primary importance on the contemporary social scene.

According to the statistics in the National Register for Adoptions, on 30.06.2016, the number of adoptable children amounted to 3250, out of which 2716 represented the number of nationally adoptable children and 534 the number of internationally adoptable children. The number of the families/persons certified for adoption, with the statement in force on 30.06.2016 was 1881, out of whom 1800 certified for national adoption and 81 certified for international adoption (National Authority for the Protection of Children Rights and Adoptions, s. a.).

The theoretical part of this study is split into three subparts, which present the abandonment and its effects, the Adoption and integration of the child in the adoptive family.

Child abandonment is defined as "an extreme form of his separation from the parents. We understand by abandoned child every child who doesn't live with his parents/one of his parents and the responsibility of the growth, education and care is transferred to an institution or to another person who is not his relative." (Miftode, 2002, p. 262)

\footnotetext{
${ }^{1}$ Transilvania University of Braşov

${ }^{2}$ Transilvania University of Braşov, dima.gabriela@unitbv.ro, corresponding author.
} 
The causes of the social phenomenon of child abandonment include (Miftode, 2002):

- The absence of material conditions, due to poverty;

- The absence of support for the mother, from the part of the extended family;

- The lack of services for mothers;

- The lack of social-care services which can act in the key point of the abandonment process: the prevention of the abandonment;

- The death of one of the parents;

- The presence of a disability in the child;

- The number of births;

- The presence of an example of abandonment in the life or in the family of one of the partners or in their entourage.

According to the legislation (Law 272/2004) for abandoned children, the special protection measures are either residential care or family type care - foster care or adoption. Compared to the other forms of adoption, for those children who are legally declared abandoned, the adoption is a permanent solution and in the highest interest of the child.

The adopted children, before obtaining this status, went through the painful experience of the abandonment by the biological mother and probably, other experiences of loss and separation added there to, depending on the child's age at the moment of the adoption. The experiences of temporary residence add to the child's history, even more lost attachments, which can't remain without effects for his developing attachment. In general, post-adoption studies show that the number and the severity of problems grow with the adopted child's age at the moment of the adoption (Delfos, 2018a, 2018b).

This study is grounded in the attachment theory, as a framework to understand both abandonment and the process of attachment formation with the adoptive parents. Mary Ainsworth examined the nature of attachment, discovering several types, resorting to an examination method called Strange Situation Test and described four types of attachment (Delfos, 2018b, p. 31-32).

- The secure attachment is characteristic of children with a positive attitude in front of the people, feeling that they can rely on them;

- The insecure attachment can be of two types: anxious-avoidant and anxiousrepulsive;

- The disorganised attachment combines all the aforementioned types.

A fifth type of attachment was added - non-attachment, characteristic of abandoned children (Howe, 2005).

Once the adoption agreed upon, according to the legislation (Law 273/2004) there is a 2year post-adoption monitoring period, when "the Direction for the child's residence, by its specialized department for adoption, monitors the evolution of the child and the relationship between the respective child and the adoptive parents" (Năftănăilă, 2017, p. 52).

The literature review and fieldwork have proven that the issue of post-adoption support is a key aspect, because the adoptive parents need support and a lasting training, so they can face the challenges in a more conscious way and offer children a therapeutic environment, where they can heal their past wounds. 
This research offers an insider's perspective on the formation of the attachment relationship within adoptive families and an overview of existing post-adoption services in the Brașov area.

\section{Methodology}

The main aim of the study is to explore the experience of adoptive families in relation to the process of attachment formation with the adopted child and to identify the existing psychosocial post-adoption support services. The research questions are: (1) which are the factors facilitating a good integration of the abandoned children in the adoptive families? (2) How do the state and private institutions assume the social responsibility for the adopted children and the adopting families?

The theoretical approach used is the phenomenology, which, according to Mucchielli (apud Scârneci, 2007, p. 32) refers to the systematic investigation of the subjectivity, more exactly of the contents of the consciousness, analysing the subjective perspective of the social actors on the main studied problem, to wit the adoption, by expressing their personal experiences and feelings about that.

\section{Participants and Sampling}

The theoretical sampling was used to select the research participants; although not having a predetermined number of research items, we were guided by the relevance of the cases met in the field, with a view to achieving a theoretical saturation. During fieldwork and the participation in the support group for adoptive families, a difference between the perceptions of adoptive parents who had the child/ children for a relatively short time in their family, in comparison with those who had spent more time with him/them, was noticed. Therefore, it was decided that the sampling of the adoptive parents would follow an upward trajectory from the point of view of the period spent by the child in the adoptive family.

The adoptive families were reached through gatekeepers from the public and private social sector and, by means of snowball sampling. They were included in this study after having obtained their informed consent. As the research group was hard to reach, the sampling had to be extended, beyond the county of Brasov, as initially planned, to other counties, Bacău and Ilfov. The final research sample consisted of 11 adoptive families, who finished the adoption process from 6 months to over 20 years. The children were adopted at ages between 6 months and 9 years, from different places, such as orphanages (leagăne in Romanian), placement centres, hospitals, foster parents or directly from the street. The specialists working in the adoption field who were included in the study, carry out their activity in the General Direction of Social Work and Child Protection (one psychologist and 2 social workers), the statutory organization with responsibilities in the field and one social worker from the single NGO in Brasov offering post-adoption services - the association A New Beginning (Un nou început in Romanian). 


\section{Data Collection Methods}

The data collection methods used for this qualitative study were observation, interview and social documents, processed by triangulation, with the main goal of improving the information and completing it, as well as validating their authenticity, by checking and mutually controlling the data obtained from different sources, with different methods (Scârneci, 2007, p. 68).

The type of observation used in this scientific research was participatory, the researcher participating in three support groups organised by the humanitarian association A New Beginning, for the adoptive families from Brașov county; uncontrolled, the researcher not interfering in any way with the activity; and middleopen, the participant in the support group knowing about the scientific research.

The semi-structured interview for adoptive parents used an interview guide with predetermined questions and was completed on-line, as a preferred method by research participants. For the specialists, the expert interview was used within one faceto-face interview and one focus-group, with questions specific to their role in the private or state service, focused on the problem.

The collection of social documents is the last scientific method used in this research, its use emerging from the desire for theoretical saturation, unachieved with other methods (observation and interview). The social document collected is not a number, is not public and is unofficial, that is an article (Romanian Alliance Without Orphans, 2016) published on the site of the Romania without Orphans Alliance blog (an NGO which reunites a multitude of NGOs with the common goal of promoting/facilitating adoption), article that contains a testimony of an adoptive family from Brașov county, a family that responded to the interview. The information provided in the interview complemented thereby the information in the article.

\section{Data Analysis and Findings}

The data analysis made use of thematic analysis and storytelling.

According to Strauss and Corbin (1990, p. 57 apud Scârneci, 2007, p. 88) encoding represents "the operations which break the data, conceptualizing and putting them back together in new ways". This type of encoding is used when the analysis of the data is oriented to the variable and the interest focused on studying the predetermined themes (ibidem).

The matrix resulted after the thematic encoding of adoptive parents' responses and consists of the following themes:

- The development pattern of the attachment relationships in the adoptive families: offering love, affection, attention, patience, physical contact (especially with babies), time spent together, understanding, availability, trust, education, absence of prejudices, safety, communication and play.

- The type of difficulties encountered by children when they are integrated in a permanent family is prevailingly character-related, most parents describing the children as having a "hot", explosive or domineering character. The 
conflicts between brothers, the litigious attitude, in general, the lack of selfconfidence, school absenteeism and low school performance, in comparison with biological children and also the child-specific problems were also brought into discussion.

- The type of difficulties encountered by the adoptive parents in the process of adaptation to the new role emerges from the lack of preparation for the adoption, which most of the parents recognised, and it refers to the difficulties related to the adoption itself and also related to the relationship with the child, most of the respondents not having the experience of the relationship with their own, biologic child yet.

- The type of support for the adoptive parents in the post-adoption period is especially the support group for adoptive families; beside this, parents also have access to the State services, the adoptive families' camps, thematic workshops and psychological counselling.

- The utility and efficiency of post-adoption support is recognised by most of the respondents. The main benefit, in parent's opinion, is the counselling and then the empathy and encouragement. The post-adoption services offered by the NGOs are valued by most interviewed parents as being accessible and having a positive role in their lives.

- The State social responsibility for the adopted children and the adoptive families is considered by most of the respondents as poorly assumed.

The themes emphasised by the specialists refer to: the existing statutory and private post-adoption services; the utility of post-adoption services; the collaboration between statutory and private services in the field; the problems encountered by the adoptive families; the factors impacting he child's integration in the adoptive family; the identity issues for adoptive children; the awareness of the need for the adoptive parents' postadoption support; accessing post-adoption support; expected legislative and/or system's changes.

The presentation of the research findings continues with a literary text, using the method called storytelling to describe the special and unique world of the adoptive parents and adopted children. It has been assumed that a theory is not enough to express what is going on in this world and to describe the healing process through which these children pass, if they are properly helped by the parents in whose home they were brought. Usher compares "the realization of stories - as a method of interpretation in the qualitative research - with literature, which is also a social practice to create worlds" (apud Scârneci, 2007, p. 120). The stories have the capacity of reaching the mind and soul of the listener in a unique way, motivating, educating, transmitting values, disciplining, offering more experience, facilitating the resolution of the issues, bringing change and healing (Burns, 2011, p. 59). The therapeutic story Dew from the Heart is the result of this qualitative research on the formation of attachment relationship in the adoptive families, putting together, as in a puzzle, through storytelling, the stories of the adoptive parents and of the experts in the field of adoption, but especially the adopted children's feelings, which emerge from the actions and events described. 


\subsection{Dew from the Heart}

My name is Irina and I am seventeen years old. My best friend is called Dew. She is from the Oldenburg breed and I have been competing with her for already three years. Actually, now she is recovering after a surgery of a limb ... in fact, the both of us are recovering, after that afternoon ... It began to rain, when we were so close to the final ... Before jumping over the last obstacle, she slid ... and from that moment I knew nothing else, till I woke up in the hospital, with a broken arm. But it was not the arm that was hurting, but the thought that my Dew is on the surgery table ... my kind Dew ... my brave Dew, my only friend till not so long ...

I don't know for whom I am writing these diary pages, but I simply think that I need to talk to myself. I have never had a sociable way of being, because I have always felt myself different. My parents adopted me when I was already four years old and, before living with them, I lived in a family system centre with five kids of different ages. I don't remember to having created a special bond of friendship with them, because we were fighting very often. The cause may have been the sadness which was hidden in my heart from the moment that my eyes became open enough to see the joy of a child walking hand in hand with his mother. I thought that I would never have a mother ... Now I have one and I love her, but even she is not capable of calming down my storms and especially of protecting me from this mean world in which I live, in which it seems that I was born to be rejected by those with whom I create a bond. Like broken strings ... that's how I would call my short friendships...

When I was in primary school, there were two girls, the most popular in class, who were always making fun of me, by calling me "The adopted one!" How could I have answered them? I couldn't have denied this truth characterising my life. Mother Helen wanted to talk to the teacher and to the girls' parents, but I was afraid ... if she had done that, Christine and Amely would have made even more fun of me. There were days when they would intentionally hurt me and then threaten me that if I were to tell something to the teacher, they would beat me on the way home. I didn't understand why the other colleagues weren't defending me. Was I really so hard to be loved? At home, with mother Helen, I was careful, I always helped her with the housework and I reassured her twenty times a day that I loved her ... as if I were afraid that one day she would also realise how annoying I was and she would stop loving me and then ... she would abandon me, like the women who gave birth to me. Mother Helen told me hundreds of times that her love would never diminish, no matter what mistake I might make, but I didn't really believe her. One day, in my life, Sparky appeared, a stuffed bunny, which, when I was making a mistake, would wipe away my tears with his paw and tell me: 'Dear Irina, you are a golden treasure that fell down into the water and got wet, but remains just as valuable as before: Then, he would explain to me why I went wrong and 
ask me how I could behave the next time, in a similar situation. He also used to encourage me when I was doing my best to control my impulses and to praise me when succeeded. He was a kind 'judge', who was watching over everything I was saying and doing, but he was talking to me with so much kindness that I couldn't get upset with him. I remember that one day he witnessed a terrible scene. Mother Helen had been stopped in the traffic by a policeman, for not having parked well. When I saw the policeman, with that angry look, coming to us, I panicked and began to cry. Mother Helen tried to put me in the car and to fasten the belt, but I was continually struggling ... actually I had struggled for an hour, as Sparky told me later. Only the next day did Sparky dare to ask me what I felt in the presence of the policeman. He didn't tell me, anyway, that I had done something wrong, he just explained to me that in those moments my brain couldn't function well and he gave me a hug.

When I was twelve years old, mother Helen took me to a riding centre and I fell in love with what I saw there. So many horses and children who learned to ride them! I drew close to Dew, who was just a six years old roan then, obedient and good, trained for competitions, but without a competition partner. It took two years till we got acquainted enough with each other, so we could jump together over the obstacles ... two years for taming each other ... I was caressing her on the reddish brown hair and she was nurturing my heart with trust. Actually, Dew made me feel loved, or ... lovable, in her presence. When we jumped together, for the first time, I felt a light breeze through my hair and a breeze of freedom ... I was proud of myself and of her, I was happy for the emotions that I was feeling. It was like understanding for the first time how it feels to love yourself. And this feeling ... incredibly strong, capable to erase all these years of low selfesteem, of embarrassment for who I was, I owed it to her, to my friend, Dew.

Ever since that moment I had began to love myself, I noticed that even the others began to like me more. Sometimes, at school, I was capable of making a conversation with one of my colleagues and I even happened to be actually funny. However, the thing that amazed me most was Amely's change. One day, before the summer holidays she took a seat beside me and told me: "You know, Irina, I think I can understand you now! My parents divorced this year and it seems like ... I mean, I feel ... what I wanted to say is that I know how it feels to be abandoned. They even don't have time, anymore, for me. All that they did this year was fighting and that's why I was so mean to you ... not just to you ... I didn't know how to control the anger that I felt. Now, I would like to learn from you what to do to stop suffering. Can you help me?" I watched her with sadness. She was asking me for an elixir that I didn't have; but I knew, however, how to forget for a while all the suffering and to commit to my passion and especially, I knew how much warmth the friendship, even with an animal, could bring, because 
... that's what I learnt: children are like animals, they attach themselves to those who take care of them! I smiled to Amely and I invited her to spend some days with me, during the summer holyday. I brought her to meet Dew, which I forgot to tell you, dear diary, became mine, as mother Helen bought her for me and even if I can't bring her home, no one else can ride her, but me. So, as I was saying, I brought Amely to meet Dew and ... Lightning, which was more likely to her temperament ... and I'm not saying this with bad feelings. Now we are riding together: I with Dew and Amely with Lightning. They are not competing yet, but I and Dew are encouraging them.

Maybe there is much more to say, but tomorrow is another day. Now I want to call Amely, to go together and see a movie. We are really friends, not only riding partners ... and this is a sign ... or, at least, so is Sparky whispering to me, which is still sleeping in my bed (I'm not sure I should write this) ... a sign that I am healed! I share this joy every day with Dew, because ... she is the fresh dew from the first morning that I felt love for myself ...

\section{Discussions and Conclusions}

The attachment relationships formed within adoptive families and the post-adoption support, the two major variables of the research were outlined using the themes and categories resulting from thematic coding. The research findings show that the impact of early life experiences does not disappear, as confirmed by Bowlby and the attachment theory (Delfos, 2018a; Bowlby, 2016), but a level of understanding can be reached by the children, maturing them and making them resilient and strong. Of particular relevance was the information from the interviews of the adoptive parents that reflected the influence of the child's age on the formation of the attachment relationship, reflecting that babies attach easier than older children.

Among the key factors facilitating the attachment process, as recorded by both adoptive parents and specialists are love, attention, patience, physical contact, time spent together, understanding, trust, availability, safety, communication and play. These factors are in line with the PACE attitude recommended by Hughes (2006 apud Golding, 2008 , p. 1) to adoptive parents, involving "play", "acceptance", "curiosity" and "empathy", which stimulates their availability for being curious to understand the children's behaviour and the desire to accept it, through a feeling of empathy with their early experiences. This way, the parents help their children develop the reflexive function, which can determine them to search the mean of their early experiences and to accept them as a part of their identity. This attitude (PACE), combined with "love" takes to a "place" of healing for the adopted child, in which the parents encounter their emotional needs of love, protection, care and understanding.

The post-adoption services, needed so much by the adoptive parents, as emphasized by all participants, even those who are not aware enough, could be improved. For example, Harris (2004) recommended support groups for the adopted adolescents' 
parents. These kind of groups could focus on problems and challenges specific to the adolescence period, which by its nature is a delicate period in life and much more for young persons who have experienced traumas and maybe didn't have the courage to face them during childhood.

The contributions of this study are its in-depth dimension and the inclusion, within the study participants, of the adoptive parents of children and young adults of different ages, adopted recently or a long time ago. Its originality relies in the story "Dew from the heart" grounded in the study findings and reflecting in a metaphoric way the healing process from previous abandonment, as well as the process of attachment formation, its difficulties and favouring factors. The story is recommended to be used as a tool for both parents and professionals.

The limitations of this study include: the small number of research participants, since this is a sensitive topic to talk about; the reluctance of many families to a face-to-face interview which could have had some flexibility compared to the on-line interview, and which could have explored more in-depth some of the topics.

Given that post-adoption services are poorly developed in Romania, in order to have an overview of the good practice models, what works and what the key dimensions of its efficiency are, future research should be extended across the borders of our country.

\section{References}

Romanian Alliance without Orphans. (2016). Adopția, un răspuns la rugăciuni! [Adoption, an answer to the prayers!]. romaniafaraorfani.ro, March 14. Retrieved from www.romaniafaraorfani.ro/adoptia-un-raspuns-la-rugaciuni.

Bowlby, J. (2016). Crearea și ruperea legăturilor afective [Creation and breaking of affective bonds]. Bucharest: Trei.

Burns, W. G. (2011). 101 povești vindecătoare pentru copii și adolescenți - folosirea metaforelor în terapie [101 Healing stories for children and teens - using metaphors in therapy]. Bucharest: Trei.

Delfos, M. (2018a). Perspectiva dezvoltării după traumă [The perspective of development after trauma]. Brașov: A.P.A.R.

Delfos, M. (2018b). Atașamentul și siguranța de sine [Attachment and confidence]. Brașov: A.P.A.R

Golding, S. K. (2008). Nurturing Attachments: supporting children who are fostered or adopted. London: Jessica Kingsley.

Harris, P. (2004). User views and experiences of post-adoption services - A study of a regional post-adoption agency. Adoption \& Fostering, 28(2), 50-60.

Howe, D. (2005). Child abuse and neglect. Hampshire: Palgrave MacMillen.

Law 272/2004 on the Protection and Promotion of Children's Rights. (2004). published in the Official Monitor, nr. 557 on 23/06/2004.

Law 273 / 2004 republished in 2012 on the Legal Regime of Adoption, published in the Official Monitor nr. 259 on 19/04/2012.

Miftode, V. (Ed.) (2002). Populații vulnerabile și fenomene de automarginalizare [Vulnerable populations and self-isolation phenomenon]. lași: Lumen. 
Năftănăilă, C. A. (2017). Adopția: un act de iubire [Adoption: an act of love]. Snagov: Letras.

National Authority for the Protection of Children Rights and Adoptions (s. a.). Adoption Statistics. Retrieved from www.copii.ro/statistici.

Scârneci, F. (2009). Cercetări calitative în asistența socială. Încercări studențești [Quality research in social work. Students testing], vol. II. Brașov, Transilvania University Publishing House. 